\title{
A LOW-STRESS-DROP, LOW-MAGNITUDE EARTHQUAKE WITH SURFACE FAULTING: THE IMPERIAL, CALIFORNIA, EARTHQUAKE OF MARCH 4, 1966
}

\author{
By James N. Brune and Charence R. Alien
}

\begin{abstract}
Right-lateral surface displacement reaching $1 \frac{1}{2}$ centimeters occurred over a ten-kilometer section of the Imperial fault in association with a magnitude 3.6 earthquake on March 4, 1966, the smallest known earthquake yet associated with surface displacement. The displacement is documented by field observations of en-echelon cracking in pavement and the offset of the white center line of Highway 80 . The association of the observed displacement with the March 4 earthquake is supported by the shallow depth of the earthquake source, the high excitation of waves in the top layer of sediments, the high excitation of Love waves of period 8-15 seconds, the distribution of aftershocks, and the agreement between the source moment as calculated from the observed faulting and from the amplitudes of Love waves. Calculations based on faulting theory indicate a fault depth of $1.1 \mathrm{~km}$, a net moment of $2 \times 10^{22}$ dyne-cm, a stress drop of 1.1 bar and an energy release of $10^{17}$ ergs. The remarkable internal consistency of the various calculations provides strong support for the faulting mechanism. It is suggested that low stress drops and relatively large fault lengths may be associated with many other small earthquakes and that allowance must be made for a wide range in the stress drops and fault lengths for any given magnitude range.
\end{abstract}

\section{Field and Seismic Observations}

Surface-faulting. Right-lateral surface displacement of about $1 \frac{1}{2} \mathrm{~cm}$ occurred along the Imperial fault $8 \mathrm{~km}$ east of El Centro, California, in association with a magnitude 3.6 earthquake that was centered in this area on March 4, 1966. Although the principal area of faulting was slightly closer to El Centro than to Imperial (Figure 1), the earthquake is herein referred to as the Imperial earthquake to avoid confusion with the much larger $(M=7.1)$ "El Centro earthquake" (or "Imperial Valley earthquake") of 1940 . Both the 1940 and 1966 events were caused by displacement on the Imperial fault, which is one of the many members of the San Andreas fault system in the northern Gulf of California structural province. The Imperial fault was first recognized and named at the time of the 1940 earthquake (Buwalda and Richter, 1941), although the existence of a major structural break along this line is also indicated by geophysical evidence (Biehler et al, 1964) as well as by continuous low Quaternary fault scarps along parts of the fault trace.

On March 6, 1966 Brune noticed a $1 \frac{1}{2} \mathrm{~cm}$ horizontal offset in the white line of Highway 80 (Figure 2), $281 \mathrm{~m}$ west of the James road intersection, at the very point where the 1940 offset on the Imperial fault is known to have taken place (J. P. Buwalda, unpublished field notes). Observations in June 1966 along adjacent parts of the Imperial fault showed that en-echelon cracks indicative of small right-lateral 
displacements of the order of $1 \mathrm{~cm}$ occurred both northwest and southeast of the Highway 80 locality for a total distance of at least $10 \mathrm{~km}$ along the fault (Figure 1). Particularly obvious were the zones of systematic en-echelon cracking in asphalt roads at (1) Highway 111, $3.8 \mathrm{~km}$ north of Highway 80, (2) Worthington Road, $248 \mathrm{~m}$ west of Highway 111 (Figure 3), and (3) Meloland Road, $87 \mathrm{~m}$ south of the Ross Road intersection. Stronger structures such as concrete-lined ditches generally did not show offsets, inasmuch as the small movement was apparently taken up by contraction joints and by slight rotations of individual segments. Nor

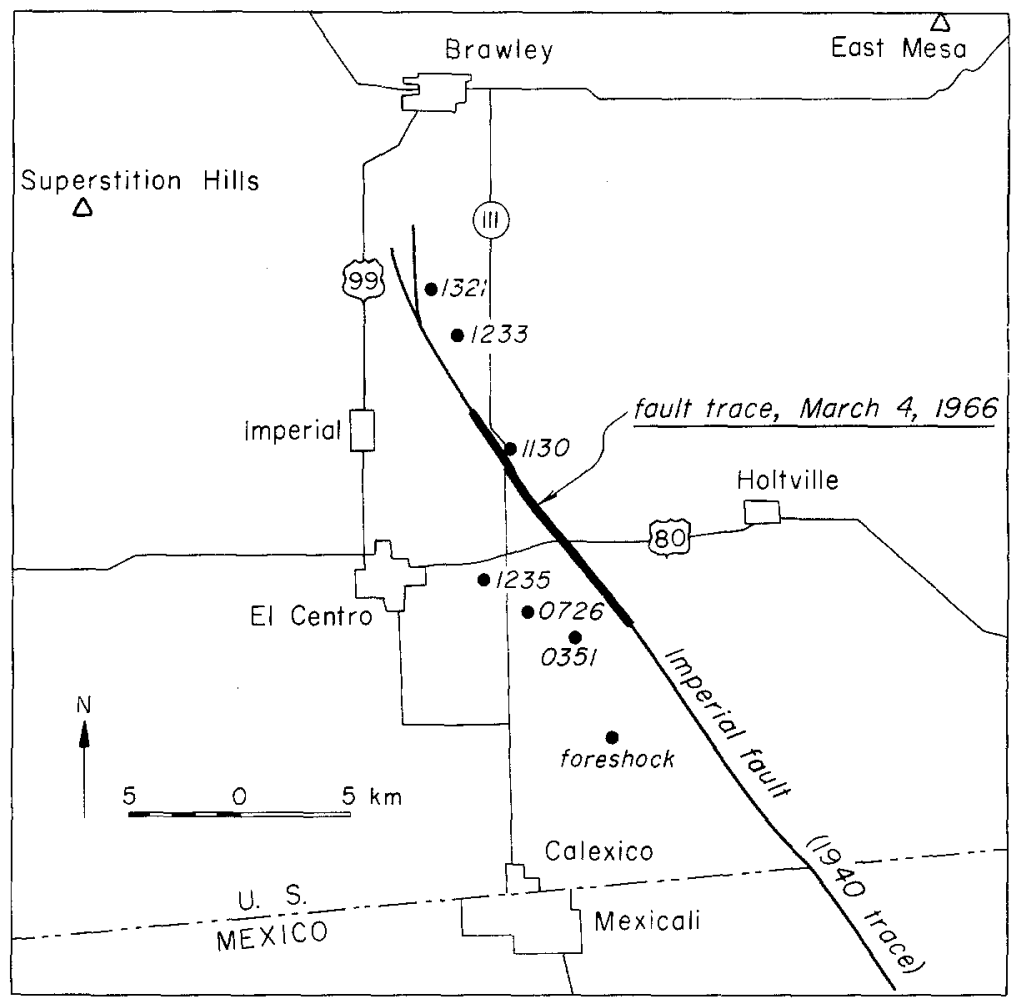

FTG. 1. Map of epicentral area, showing $10-\mathrm{km}$ trace of surface faulting during earthquake of March 4, 1966 (heavy line). Locations and times (hour and minute) of several aftershocks and a foreshock are also shown.

did every asphalt road show obvious en-echelon cracks. This is apparently caused by differences in asphalt composition, as well as the fact that the fault is not everywhere a discrete plane at the surface. Nevertheless, at every point where the modern asphalt was broken, it took place at exactly the position of the 1940 break as described by Buwalda. North of Highway 80 , these breaks occur at the base of a distinct Quaternary scarp marking the fault trace. No convincing evidence could be obtained for renewed displacements northwest or southeast of the broken segment as shown in Figure 1, although the Imperial fault was carefully examined as far south as the International border.

The fact that the westbound lanes of Highway 80 are offset along a single north- 
south fracture, rather than by an en-echelon zone of cracking such as characterizes other areas, is evidently caused by the fact that the asphalt of the westbound lanes of the present highway was laid directly on top of the concrete slabs of the pre- 1940 highway. Indeed, the contraction joints that are shown displaced and rotated in 1940 photographs are still visible as minor crasks in the much newer overlying asphalt (Figures 4, 5).

To our knowledge, the Imperial earthquake is the smallest reported earthquake associated with finite surface displacement along a fault. It points up the need for

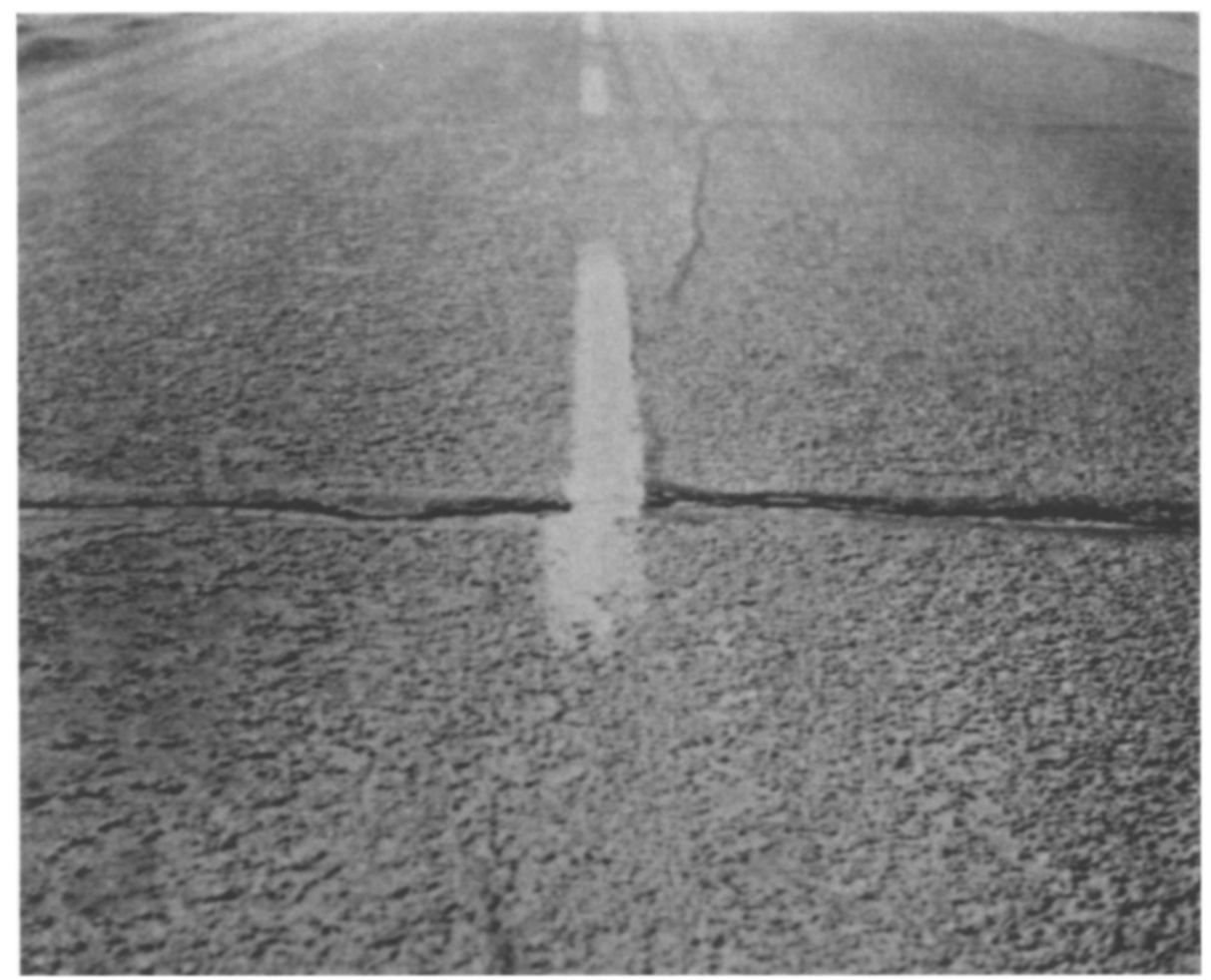

FIG. 2. Offset of white line at Highway 80 locality, March 6, 1966. Right-lateral displacement is about $1 \frac{1}{2} \mathrm{~cm}$.

careful field observations along faults following even relatively small earthquakes, and it emphasizes once again the problems associated with structures placed athwart active fault zones.

Seismic data. The epicenter assigned to the Imperial earthquake by the computer location program of the Seismological Laboratory is $32^{\circ} 52.9^{\prime} \mathrm{N} ., 115^{\circ} 33.3^{\prime} \mathrm{W}$, which is about $4 \mathrm{~km}$ northeast of Imperial and very nearly on the extended trace of the fault break. The solution agrees well with the arrival times at all the nearby stations (El Centro, Barrett, Palomar, Hayfield) but, nevertheless, cannot be considered accurate to within $10 \mathrm{~km}$ because of uncertain travel times related to the 6-km-thick sedimentary section and the thin crust in this region. 
An extremely shallow focal depth for the March 4 th event is indicated by several lines of seismic evidence:

(1) The $S-P$ time at El Centro is about 1.3 sec for the first-arriving waves, which apparently have been refracted through the $5 \mathrm{~km} / \mathrm{sec}$ sedimentary layer identified by Biehler (1964). This indicates a distance of about $8 \mathrm{~km}$. If the epicenter lies along the fault, the depth must, therefore, be less than about $3 \mathrm{~km}$.

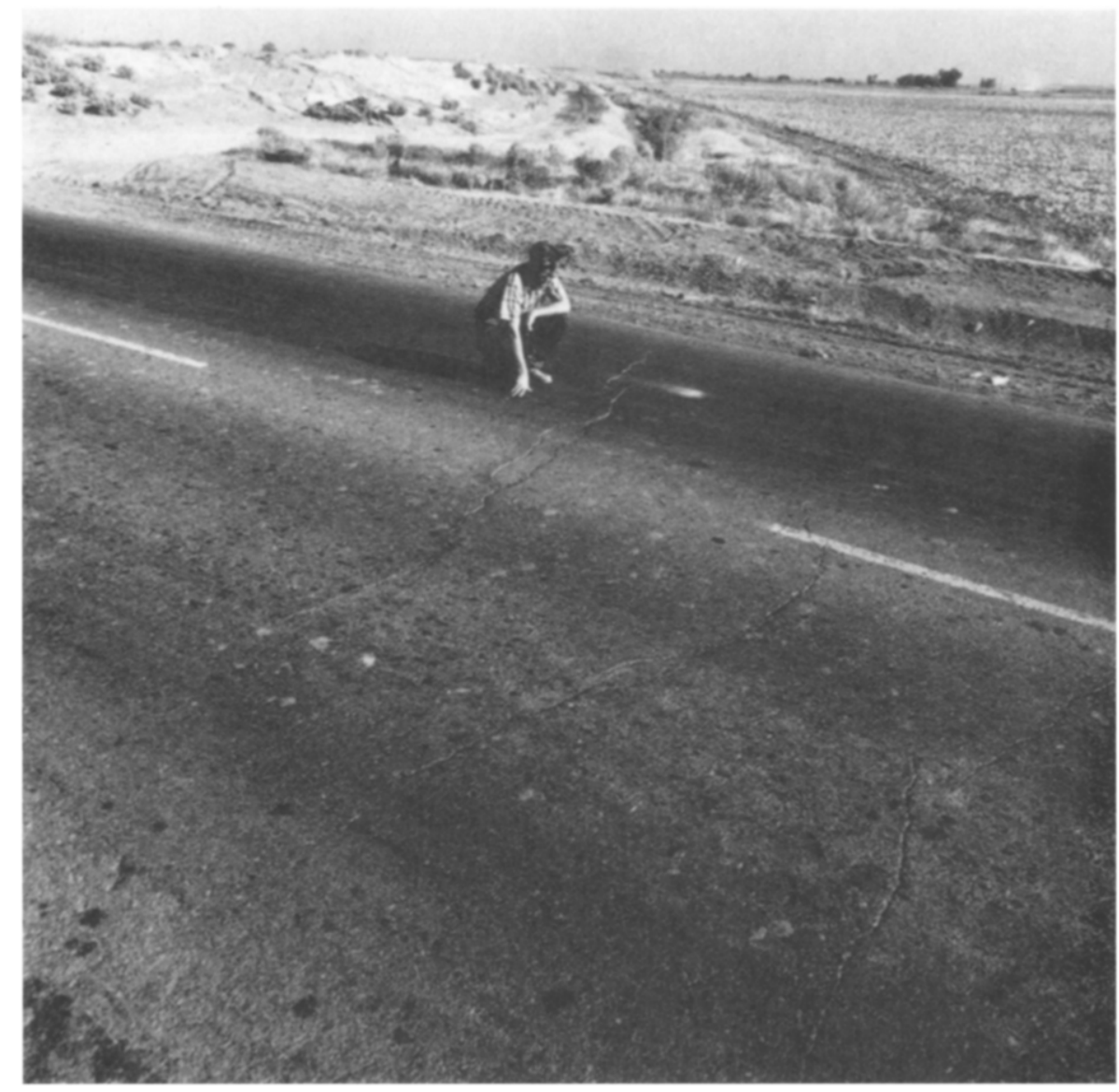

FIG. 3. En-echelon cracks along fault trace at Worthington Road. Quaternary fault scarp in background.

(2) Remarkably high-amplitude $P$ and $S$ waves travelling through the uppermost sedimentary layers (alluvium and lake beds) have an $S-P$ time of 2.9 sec, giving a distance of about $7 \mathrm{~km}$. These arrivals were identified using the refraction results of Biehler (1964) and have $P$ and $S$ wave velocities of 1.7 and $1.0 \mathrm{~km} / \mathrm{sec}$ respectively. The high excitation of these waves and their travel times both indicate a source depth less than $3 \mathrm{~km}$, and the high amplitudes $(.015 \mathrm{~cm}$ or $.06 \mathrm{~g}$ for the highest amplitude wave) in particular suggest that whatever the point of initial rupture, the rupture during the earthquake extended into the 0.2 -km-thick surface layer, and probably to the surface. 


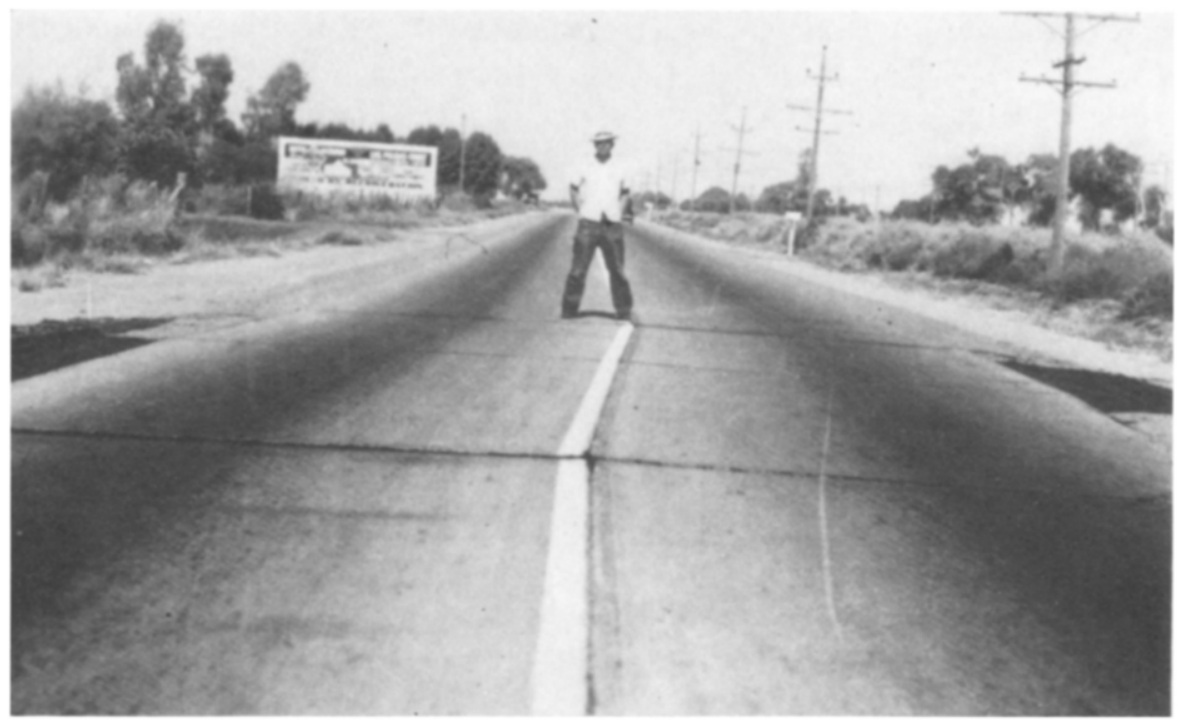

Fig. 4. Rotated concrete slab at Highway 80 locality 6 days following Imperial Valley earthquake of May 18, 1940. Displacement was $46 \mathrm{~cm}$ as measured both along extended trace of white line and along pole line (right). Photograph by Harold M. Engle.

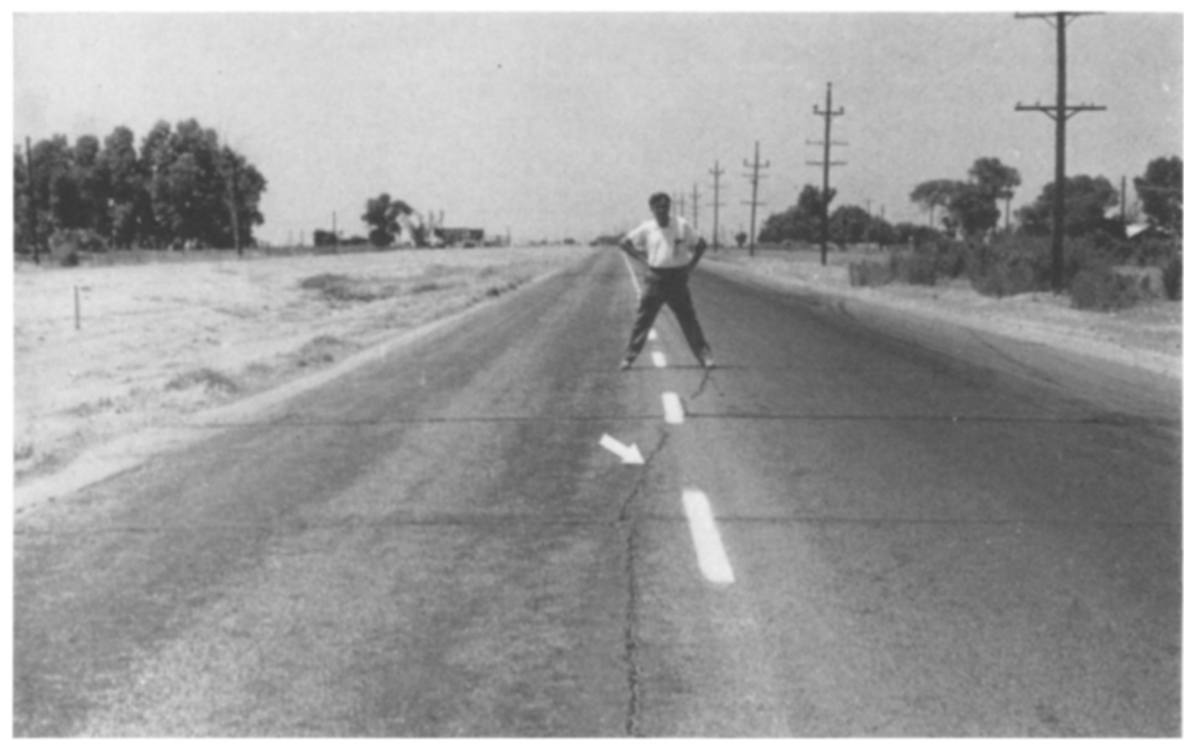

FIG. 5. Highway 80 locality in July 1966. Concrete joints of Figure 4 show as eracks in overlying asphalt (arrow). Displacement of former center line is now about $84 \mathrm{~cm}$, pole line about $79 \mathrm{~cm}$. $1 \frac{1}{2} \mathrm{~cm}$ displacement of March 4, 1966, (Fig. 2) took place at cross-joint just above arrowhead.

(3) The high excitation of fundamental-mode Love waves of period about 8 sec indicates a source depth less than about one-quarter wavelength, i.e., less than about $7 \mathrm{~km}$.

(4) The relatively high accelerations and intensity at El Centro as compared to the magnitude (Richter, 1958, p. 353) indicate a shallow source. 
The magnitude of the earthquake as registered at Pasadena was 3.6, although successively more distant stations of the southern California network registered successively larger magnitudes ( 3.4 at Barrett to 3.9 at Tinemaha). In the epicentral area, the maximum intensity was about MM V, but the shaking was not of sufficient intensity to trigger the CGS strong-motion instrument at El Centro, about $7 \mathrm{~km}$ distant. The maximum ground amplitudes at El Centro were $0.015 \mathrm{~cm}$ at about $6 \mathrm{cps}$; the corresponding accelerations were about $0.06 \mathrm{~g}$. This would suggest an intensity of about 6-7 (Richter, 1958, p. 140), significantly higher than that indicated from felt reports. The high accelerations were associated with a single oscillation of the surface waves travelling in the low velocity surface layer of alluvium and lake beds, and as mentioned above, indicate the rupture extended into this layer.

A number of aftershocks of the March 4th event were recorded by two microearthquake trailers (Brune and Allen, in press) which were placed in operation at Superstition Hills and East Mesa (Figure 1) about twenty-two hours after the event and recorded for about twenty-four hours. These stations were both within $30 \mathrm{~km}$ of the epicentral region. Aftershocks were located by using $S-P$ times and requiring consistency with $P$-wave arrival times. The depth of focus was assumed to be shallow, about $2-4 \mathrm{~km}$, and a $P$-wave velocity for basement rocks was taken as $5.5 \mathrm{~km} / \mathrm{sec}$ as found by Biehler et al (1964). The epicenters determined in this manner are shown in Figure 1. In addition, a somewhat similar seismograph layout five days prior to the earthquake had recorded a foreshock whose location is also shown on Figure 1. The uncertainty in location is of the order of $\pm 3 \mathrm{~km}$ in any direction for each event. The epicenters clearly indicate an extended zone of energy release as might be expected from motion along the trace of the fault shown in Figure 1.

Sudden faulting or accelerated creep? The offset of the white line first observed by Brune on March 6th had taken place sometime during the previous six months, inasmuch as the line had last been repainted in September 1965. Although one might argue that the observed displacement had taken place gradually as creep, it appears highly probable that it instead took place suddenly during the March 4th earthquake, and indeed caused the earthquake. This is suggested by the following lines of evidence: (1) The earthquake of March 4th was centered in this very area and was sharply felt here. (2) As was discussed in the previous section, the source of the Imperial shock was clearly within the uppermost sedimentary layers, so that the association of the surface faulting with the earthquake is a logical and persuasive argument. (3) There is no evidence of earlier or later creep at this locality, as indicated by earlier generations of white lines as well as two repaintings since the earthquake. (4) In the fields immediately north of the highway, Mr. Clarke Raymond states that buried drainage tile was slightly displaced along the line of the Imperial fault at about the time of the March 4th shock. (5) Epicenters of aftershocks clearly outline the elongate area of the fault trace (Figure 1) and give strong support to the association of movement along this section of the fault with the Imperial earthquake.

In addition to the above lines of evidence, long-period Press-Ewing seismograph records from Pasadena and Goldstone support the hypothesis that motion along the section of the fault shown in Figure 1 took place in connection with the three earth- 
quakes on March 4th and, in particular, in connection with the earthquake of 1240 GMT. Three shocks of greater than magnitude 3.0 occurred in this area on March 4 th, at 1052, 1240, and 1425 GMT. These were assigned magnitudes of 3.5, 3.6, and 3.3, respectively, by Pasadena. The 1240 shock generated particularly large Love waves of period $8-18$ seconds ( $\sim 0.7 \mu$ at 13 seconds period at Pasadena and Goldstone), at least five times greater than for the other two events. Thus it is reasonable to associate motion along the section of the fault outlined in Figure 1 with the 1240 event, since motion along such a large section of the fault would cause relatively high excitation of surface waves of this wavelength $(30-50 \mathrm{~km})$. Similarly, relatively large surface waves were recorded for the 1240 shock at Albuquerque and Tucson. In particular, Tucson received relatively high-amplitude Rayleigh waves, as would be expected from the radiation pattern of a strike-slip fault of the orientation observed in the field.

One might argue that the observed faulting is associated with the earthquake only indirectly, in that the faulting that caused the earthquake was limited to a small volume along the fault at a depth of perhaps $2 \mathrm{~km}$, and that the surface faulting was a gradual creep phenomenon that was triggered by the earthquake and followed it within the next few hours. Inasmuch as no one observed the surface faulting taking place, we cannot prove that it occurred at the same time as the earthquake, but we feel that everything logically points to this conclusion. Certainly the 1240 shock had a considerably larger source dimension than the other shocks of similar magnitude that occurred that day, as indicated by the surface waves; and the high amplitude sedimentary waves excited by the earthquake suggest large motions near the surface. More important, as is discussed in a later section, it is remarkable that the fault parameters observed in the field are in every way mechanically consistent with the theory of fault origin, which would be a most unlikely coincidence if the surface faulting merely represented a subsequent creep that was somehow triggered by the earthquake. The same argument can be applied to the 1966 Parkfield earthquake, where Aki (1967) likewise demonstrated that the observed faulting is mechanically consistent with the theory that it caused the earthquake, and McEvilly's (1966) fault-plane solution indicates that at least the triggering movement was of the same sense as that observed along the entire $38-\mathrm{km}$ surface break.

Fault creep prior to the earthquake. Horizontal creep on the Imperial fault was suggested by Whitten (1956) on the basis of discontinuities in the displacement vectors resulting from triangulation surveys in 1941 and 1954. Along the approximate line of Highway 80, Meade (1963) calculated an annual lateral displacement during this period of $3.1 \mathrm{~cm}$ between stations at Holtville and El Centro, each $7-10 \mathrm{~km}$ from the fault on opposite sides. This would extrapolate to a total of about $77 \mathrm{~cm}$ displacement between 1941 and 1966. Reconnaissance observations along the trace of the Imperial fault at several times prior to 1966 , however, had failed to reveal offset cultural features other than those few still remaining from the 1940 earthquake. In particular, Allen had retraced the entire line in February 1964 and found no convincing evidence of active creep in fence lines, concrete-lined ditches, or roads. Supporting the idea of further displacements at some time between 1940 and 1966, nevertheless, is the fact that the present offset of pre-1940 features at the Highway 80 locality is significantly greater than that measured by Buwalda six days after 
the 1940 earthquake: The offset of the telephone-pole line north of the highway is now $79 \mathrm{~cm}$, and the center line of the old concrete pavement is now offset about 84 $\mathrm{cm}$, as compared with Buwalda's measurement of $18^{\prime \prime}(46 \mathrm{~cm})$ for both features. This is particularly obvious when Engle's 1940 photograph (Figure 4) is compared with a photograph of the same spot today (Figure 5).*

Thus there can be little doubt that further displacements along the Imperial fault have taken place following the time of Buwalda's measurements and Engle's photograph, and prior to the time of the latest minor slip. The measurement on the pole line and highway indicate, however, that this displacement cannot be greater than about $35 \mathrm{~cm}$, which is considerably less than the $77 \mathrm{~cm}$ extrapolated from the geodetic data for the same period. Assuming the geodetic data to be correct, this implies either that the displacements ceased following the 1954 geodetic observations, or that the measured displacement between El Centro and Holtville is not entirely reflected in creep on the Imperial fault. One might also argue that much or all of the post-earthquake displacement inferred from the Highway 80 measurements took place during the aftershock sequence in the months following the 1940 event; indeed, it is well documented that continuing fault displacements were still taking place at the time of Buwalda's visit (Richter, 1958, p. 75). The continuing displacements on the San Andreas fault following the 1966 Parkfield earthquake (Allen and Smith, 1966), which in some areas exceed the probable displacement during the earthquake itself, demonstrate that this is a likely possibility. In any event, it is probable that the strain indicated by the post- 1940 geodetic measurements is not all reflected in creep along the Imperial fault, and that an ample source of strain energy thus exists for small earthquakes of the type that occurred on March 4, 1966.

\section{Mechanism of Strain Release}

Using the theoretical results of Haskell (1964), Burridge and Knopoff (1964), and Maruyama (1963), as used by Aki $(1966,1967)$ in a study of the Niigata and Parkfield earthquakes, we may calculate whether the observed displacements in the field are consistent with the amplitude of Love waves recorded at Pasadena and Goldstone. Assuming a focal depth of $0-5 \mathrm{~km}$ for the equivalent point source, a crustal thickness of $35 \mathrm{~km}$, and a double-couple corresponding to a strike-slip fault oriented as indicated by the field evidence, the moment at the source corresponding to the observed amplitude of Love waves is $2 \times 10^{22}$ dyne-cm. Following the authors referred to above, this moment may be equated to the product of the rigidity, fault area, and average displacement:

$$
M_{0}=\mu A \bar{U}
$$

Inasmuch as the rocks of the Imperial Valley are clastic sedimentary strata to a depth of at least $6 \mathrm{~km}$, the rigidity is taken to be about $2 \times 10^{11} \mathrm{dyne} / \mathrm{cm}^{2}$. Field evidence indicates a fault length of $10 \mathrm{~km}$. To test whether the observed faulting reasonably explains the observed seismic waves, we use the observed average dislo-

\footnotetext{
* Careful examination of Engle's photograph indicates that Ulrich's (1941, Figure 1) estimate of $2 \frac{1}{2} \mathrm{ft}$ offset is either mistaken or represents a measurement taken at a later time. Buwalda's measurement of $18^{\prime \prime}$ is supported by Highway Department figures (Wallace, 1940).
} 
cation of about $0.9 \mathrm{~cm}$ and find that the fault depth must be $1.1 \mathrm{~km}$. This is a reasonable figure that is mechanically compatible with the known fault length and agrees well with the seismological evidence. We conclude, therefore, that the excitation of the Love waves recorded at Pasadena and Goldstone is consistent with the observed fault slippage. This argument was used in a previous section to support the idea of a direct causal relationship between the observed fault and the earthquake.

The stress-drop during the earthquake can be estimated by using the various fault parameters observed in the field. Three theoretical results are available for this purpose:

(1) For a dip-slip displacement along an infinitely long narrow strip in a uniform shear field, Starr (1928) gives

$$
\sigma \cong \frac{4}{3} \frac{U, \mu}{w}
$$

where $\sigma=$ stress-drop, $U_{m}=$ maximum displacement, $\mu=$ rigidity, and $w=$ width (i.e., fault-plane dimension perpendicular to its strike).

(2) For an infinitely long vertical surface fault with strike-slip displacement, Knopoff (1958) gives

$$
\sigma=\frac{1}{2} \frac{U_{r} \mu}{w}
$$

(3) For a circular fault plane in an infinite medium, Keylis-Borok (1959), using the results of Neuber (1937), gives

$$
\sigma=\frac{2 \pi}{3} \frac{U_{m} \mu}{w}
$$

Thus the average dislocation, the rigidity, and the fault width are related by the general equation

$$
\sigma \cong \eta \frac{U_{m} \mu}{w}
$$

where $\eta$ takes on various values ranging from $\frac{1}{2}$ to $2 \pi / 3$ depending on the fault geometry. For all these cases the displacement averaged over the fault surface is about $\frac{3}{4}$ the maximum displacement. In our case we estimate $\eta$ to be about $\frac{1}{2}$, i.e., approximately case (2). The stress-drop is then

$$
\sigma=\frac{1}{2} \frac{U_{m} \mu}{w}=1.1 \text { bar. }
$$

This is an extremely low-stress-drop compared to values often obtained for large earthquakes (Table 1), but is of the same order of magnitude as that found by Aki (1967) for the 1966 Parkfield earthquake.

The seismic energy-versus-magnitude relationship of Gutenberg and Richter 
(1956), $\log E=11.8+1.5 M$, gives $1.6 \times 10^{17}$ ergs for a magnitude 3.6 shock. The El Centro seismogram also indicates that the total seismic energy radiated is about $2 \times 10^{17} \mathrm{ergs}$. This energy release is consistent with the low stress-drop and faulting observed in the field: If the stress drops from 1.1 bar to 0 , and if the mean displacement is $0.9 \mathrm{~cm}$, the fault length $10 \mathrm{~km}$, and the fault depth $1.1 \mathrm{~km}$, then the energy release should be $6 \times 10^{16}$ ergs. Within the expected accuracy, this agrees with the energy calculated from the Gutenberg-Richter formula. The excess may be an indication that the pre-stress was significantly higher than the stress-drop (Burridge and Knopoff, 1966), especially if allowance is made for imperfect efficiency in generation of seismic waves, but the uncertainties are too great to make a strong statement.

TABLE 1

Order-of-Magnitude Stress-Drops for Various Earthquakes (Symbols are defined in text)

\begin{tabular}{|c|c|c|c|c|c|c|c|c|}
\hline Earthquake & Date & Mag. & $\begin{array}{l}\text { Length } \\
(\mathrm{km})\end{array}$ & $\begin{array}{l}\text { Width } \\
(\mathrm{km})\end{array}$ & $\begin{array}{l}\mathrm{U}_{m} \\
(\mathrm{~m})\end{array}$ & $\eta$ & (bars) & References \\
\hline Alaska & 1964 & 8.5 & 600 & 200 & 13.3 & $4 / 3$ & 27 & Savage and Hastie (1966) \\
\hline $\begin{array}{l}\text { San Fran- } \\
\text { ciseo }\end{array}$ & 1906 & 8.3 & 450 & 10 & 4.9 & $1 / 2$ & 74 & $\begin{array}{l}\text { Lawson et al (1908); } \\
\text { Walsh (1966) }\end{array}$ \\
\hline Mongolia & 1957 & 8.3 & 280 & 20 & 4.7 & $1 / 2$ & 35 & $\begin{array}{l}\text { Florensov and Solonenko } \\
\text { (1963) }\end{array}$ \\
\hline Kern County & 1952 & 7.8 & 50 & 20 & 0.6 & $4 / 3$ & 12 & $\begin{array}{l}\text { Whitten (1955); Cister- } \\
\text { nas (1963) }\end{array}$ \\
\hline Niigata & 1964 & 7.5 & 100 & 20 & 5.3 & $4 / 3$ & 106 & Aki (1966) \\
\hline Turkey & 1953 & 7.2 & 50 & 15 & 4.3 & $1 / 2$ & 43 & Ketin and Roesli (1953) \\
\hline $\begin{array}{l}\text { Imperial } \\
\text { Valley }\end{array}$ & 1940 & 7.1 & 60 & 10 & 1.7 & $1 / 2$ & 25 & $\begin{array}{l}\text { Buwalda (unpublished } \\
\text { field notes) }\end{array}$ \\
\hline $\begin{array}{l}\text { Fairview } \\
\text { Peak }\end{array}$ & 1954 & 7.1 & 36 & 6 & 2.7 & $4 / 3$ & 180 & Savage and Hastie (1966) \\
\hline Montana & 1959 & 7.1 & 30 & 15 & 13.3 & $4 / 3$ & 355 & Savage and Hastie (1966) \\
\hline San Miguel & 1956 & 6.8 & 19 & 5 & .85 & $1 / 2$ & 25 & Shor and Roberts (1958) \\
\hline Parkfield & 1966 & 5.5 & 38 & 12 & .05 & $1 / 2$ & 0.6 & $\begin{array}{l}\text { Allen and Smith (1966); } \\
\text { Aki (1967) }\end{array}$ \\
\hline Imperial & 1966 & 3.6 & 10 & 1.4 & .015 & $1 / 2$ & 1.1 & this paper \\
\hline
\end{tabular}

The stress-drop of 1.1 bars appears especially low when it is compared with the hydrostatic stress at the deepest part of the fault, which is two orders of magnitude higher. Although this poses a severe mechanical problem, it is the same problem that is faced in trying to explain most other earthquakes as well. There is no evidence of excessive fluid pore pressures at these depths in this part of the Imperial Valley, but there is abundant evidence of tectonic extension across this part of the Gulf of California structural province (Biehler et al, 1964; Allen et al, 1965) that might cause the normal stress on the fault here to be less than that farther north along the San Andreas system, thus aiding very shallow fracturing at relatively low stresses.

\section{Comparisons with other EARTHQUAKES}

Although all of the above calculations are subject to some uncertainties, it seems clear that the 1966 Imperial earthquake, and perhaps many other small shocks, are 
associated with relatively small stress-drops and relatively large source dimensions. A recent study by Press (1965) surmised that if extrapolations to small magnitudes were made assuming earthquake-producing strains of $10^{-4}$, with consequent stressdrops on the order of 100 bars, then magnitude 4.0 earthquakes would be expected to have fault lengths of the order of 0.1 to $1.0 \mathrm{~km}$. On the other hand, our results indicate that earthquakes with magnitudes as small as 3.6 may have surface fault lengths of as much as $10 \mathrm{~km}$. This surprising result agrees neither with Press's calculations, nor with the extrapolated curves of Tocher (1958) and Iida (1959) that are based mainly on earlier field observations of faulting for larger earthquakes, as is illustrated by Figure 6 . This wide variation in behavior may help to explain the study by Brune et al (1963) which indicated that many of the earthquakes in the

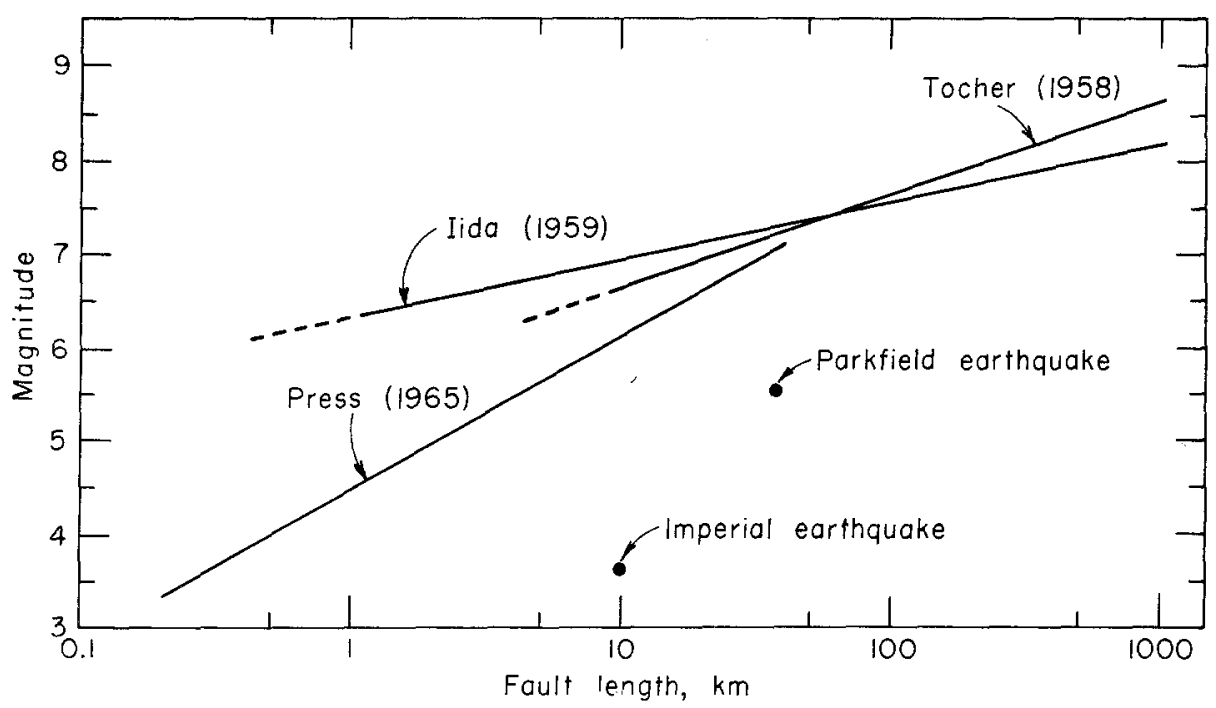

FIG. 6. Graph of magnitude vs. fault length.

California-Nevada region with magnitudes between 3.5 and 4.0 generated abnormally large surface waves similar to those of the March 4 th event at Imperial.

Further suggestion of the great differences in stress-drops for various earthquakes is given by Table 1, which shows order-of-magnitude stress-drops for a number of earthquakes for which the field or seismic evidence allows rough assignment of the parameters used in the equations of the previous section. Many uncertainties are involved in assigning these parameters for particular shocks; for example, the estimate of fault width (usually corresponding to fault depth) is in some cases little more than a guess. Furthermore, it was assumed in every case that the described faulting was indeed the cause of the earthquake, which might be debated in some examples. Another source of complication is the relationship between maximum and average fault displacement. Although the displacement at any given point along the surface trace of a fault may be close to the average displacement with depth at that point, two well-studied earthquakes indicate that the maximum displacement observed on the surface may be very different from the average displacement along the surface trace of the fault: (1) The maximum displacement observed near the center 
of the 1940 Imperial Valley fault was $5.8 \mathrm{~m}$ (Richter, 1958), but a weighted average of more than 30 individual measurements by Buwalda (unpublished field notes) along all parts of the $60-\mathrm{km}$ trace indieates that the average displacement was only about $1.25 \mathrm{~m}$; (2) Florensov and Solonenko's (1963) map of the 1957 Mongolian break indicates an average strike-slip of about $3.5 \mathrm{~m}$, based on 23 distributed individual measurements, whereas the well-documented maximum displacement was $8.85 \mathrm{~m}$. Consequently, for the purpose of calculating the stress-drops of Table 1 , the maxîmum displacement has in most cases been obtained by multiplying a reasonable figure for the average displacement by $4 / 3$, rather than by using the maximum displacement actually observed in the field. It should be further noted that for the cases which yield the highest stress drops (greater than 100 bars), the displacements used were obtained from theoretical interpretations rather than by direct field observations. For all shocks, we assume $\mu=3 \times 10^{11} \mathrm{cgs}$ units, with the exception of the 1966 Imperial earthquake where a value of $2 \times 10^{11}$ was used because the earthquake source was clearly within the soft sedimentary section.

Despite these many complicating factors, the great spread in calculated stressdrops of Table 1 suggests to us that there is a wide variation in the character of ruptures that occur in surface faulting: Relatively high stress-drops occur in some cases, and much smaller stress-drops in others; in addition, creep episodes of the type described by Tocher (1960) occur with virtually no radiation of seismic energy. These variations in stress-drop are much greater than those suggested by Chinnery (1964). However, recent work on the stick-slip fault mechanism by Brace and Byerlee (1966) indicates that even this variation does not necessarily imply great differences in total stress prior to failure.

We feel that our conclusions concerning the Imperial earthquake, if valid, have significant implications to several important seismological problems. For example, they suggest that the source dimensions of shallow earthquakes may be considerably larger than the source dimensions of equivalent-magnitude explosions. They also suggest that a scaling law based on the similarity of all earthquakes, such as is suggested by Aki (1967), is not valid. Finally, the fact that all of the calculations based on the various measured field and seismic parameters of the Imperial earthquake, and based on an assumption of the fault origin of the earthquake, yield internally consistent results implies to us that the fault origin of this earthquake-and probably many other shallow shocks-is very strongly supported.

\section{ACKNOWLEDGMENTS}

These observations were carried out in connection with a broader study of active faults in southern California supported by National Science Foundation grant GP-2806 (Upper Mantle Project). Critical comments of Drs. Arden Albee and Leon Knopoff are appreciated.

\section{References}

Aki, K. (1966). Generation and propagation of $G$ waves from the Niigata earthquake of June 16, 1964. Part 2. Estimation of earthquake moment, released energy, and stress-strain drop from the $G$ wave spectrum, Bull. Earthquake Res. Inst. Tokyo Univ. 44, 73-88.

Aki, K. (1967). Scaling law of seismic spectrum, J. Geophys. Res. 72, 1217-1231.

Allen, C. R. and S. W. Smith (1966). Parkfield earthquakes of June 27-29, 1966: Pre-earthquake and post-earthquake surficial displacements, Bull. Seism. Soc. Am. 56, 966-967.

Allen, C. R., P. St. Amand, C. F. Richter and J. M. Nordquist (1965). Relationship between 
seismicity and geologic structure in the southern California region, Bull. Seism. Soc. Am. $5 \tilde{5}, 753-797$.

Biehler, S. (1964). Geophysical Study of the Salton Trough of Southern California, (Unpublished Ph.D. Thesis), Calif. Inst. of Tech., Pasadena.

Biehler, S., R. L. Kovach and C. R. Allen (1964). Geophysical framework of northern end of Gulf of California structural province, Am. Assoc. Petroleum Geologist Memoir 3, 126-143.

Brace, W. F. and J. D. Byerlee (1966). Stick-slip as a mechanism for earthquakes, Science, $153,990-992$.

Brune, J. N., and C. R. Allen (1967). A micro-earthquake survey of the San Andreas fault system in southern California, Bull. Seism. Soc. Am. 57 (in press).

Brune, J. N., A. Espinosa and J. E. Oliver (1963). Relative excitation of surface waves by earthquakes and underground explosions in the California-Nevada region, J. Geophys. Res. 68, 3501-3513.

Burridge, R. and L. Knopoff (1964). Body force equivalents for seismic dislocations, Bull. Seism. Soc. Am. 54, 1875-1888.

Burridge, R. and L. Knopoff (1966). The effect of initial stress or residual stress on elastic energy calculations, Bull. Seism. Soc. Am. 56, 421-424.

Buwalda, J. P. and C. F. Richter (1941). Imperial Valley earthquake of May 18, 1940, (Abstract), Bull. Geol. Soc. Am. 52, 1944.

Chinnery, M. A. (1964). The strength of the earth's crust under horizontal shear stress, $J$. Geophys. Res. 69, 2085-2089.

Cisternas, A. (1963). Precision determination of focal depths and epicenters of local shocks in California, Bull. Seism. Soc. Am. 53, 1075-1083.

Florensov, N. A. and V. P. Solonenko (1963). The Gobi-Altai Earthquake. Isdatel'stvo Akademii Nauk SSSR, Moseow, 392 p. (English translation by Israel Program for Scientific Translations, 1965).

Gutenberg, B. and C. F. Richter (1956). Magnitude and energy of earthquakes, Ann. Geofis. 9, 1-15.

Haskell, N. A. (1964). Radiation pattern of surface waves from point sources in a multi-layered medium, Bull. Seism. Soc. Am. 54, 377-393.

Iida, K. (1959). Earthquake energy and earthquake fault, J. Earth Sci., Nagoya Univ. 7, 98-107.

Ketin, I. and F. Roesli (1953). Makroseismische uber das nordwestanatolische Beben vom 18. Marz 1953, Eclogae Geologicae Helvetiae, 46, 187-208.

Keylis-Borok, V. I. (1959). On estimation of the displacement in an earthquake souree and of source dimensions, Annali Geofisica, 12, 205-214.

Knopoff, L. (1958). Energy release in earthquakes, Geophys. J. 1, 44-52.

Lawson, A. C., et al (1908). The California Earthquake of A pril 18, 1906, Carnegie Inst. Washington Pub. 87.

Maruyama, T. (1963). On the force equivalents of dynamic elastic dislocations with reference to the earthquake mechanism, Bull. Earthquake Res. Inst. Tokyo Univ. 41, 467-486.

McEvilly, T. V. (1966). Parkfield earthquakes of June 27-29, 1966: Preliminary seismic data, June-July, 1966, Bull. Seism. Soc. Am. 56, 967-971.

Meade, B. K. (1963). Horizontal crustal movement in the United States, Rept. to Commission on Recent Crustal Movements, Int. Union of Geodesy and Geophysics, General Assembly, Berkeley, $25 \mathrm{p}$.

Neuber, H. (1937). Kerbspannungslehre, Berlin, Springer-Verlag, 161 p.

Press, F. (1965). Dimensions of the Source Region for Small Shallow Earthquakes, unpublished VESIAC report.

Richter, C. F. (1958). Elementary Seismology, San Francisco, W. H. Freeman and Co., 768 p.

Savage, J. C. and L. M. Hastie (1966). Surface deformation associated with dip-slip faulting. J. Geophys. Res. 71, 4897-4904.

Shor, G. G., Jr. and E. Roberts (1958). San Miguel, Baja California Norte, earthquakes of February, 1956: a field report, Bull. Seism. Soc. Am. 48, 101-116. 
Starr, A. T. (1928). Slip in a crystal and rupture in a solid due to shear, Cambridge Phil. Soc. Proc. 24, 489-500.

Tocher, D. (1958). Earthquake energy and ground breakage, Bull. Seism. Soc. Am. 48, 147-153.

Tocher, D. (1960). Creep rate and related measurement at Vineyard, California, Bull. Seism. Soc. Am. 50, 396-404.

Ulrich, F. P. (1941). The Imperial Valley earthquakes of 1940, Bull. Seism. Soc. Am. 31, 13-31.

Wallace, E. E. (1940). Small damage to state highways by Imperial Valley earthquake, California Highways and Public Works, July, 26-27.

Walsh, J. B. (1966). Permanent surface displacement accompanying faulting (Abstract), Bull. Geol. Soc. Am., Program of 1966 Annual Mtg., 234.

Whitten, C. A. (1955). Measurements of earth movements in California, California Div. Mines Bull. 171, 75-80.

Whitten, C. A. (1956). Crustal movement in California and Nevada, Trans. Am. Geophys. Union, 37, 393-398.

Seismological Laboratory

California Institute of Technology

Pasadena, Caltfornia

(Drvision of Geological Sciences, Contribution 1434).

Manuscript received December 12, 1966. 